\title{
STUDI KOMPARARTIF KUALITAS PELAYANAN DAN STRATEGI DELIVERY SERVICE PADA KENTUCKY FRIED CHICKEN (KFC) DAN MC DONALD'S CABANG BUAH BATU BANDUNG
}

\author{
Agus Maolana Hidayat (agusm.hidayat@gmail.com) \\ Fauzia Rahayu (fauziarahayu@gmail.com) \\ Telkom University, Bandung
}

\begin{abstract}
Abstrak
Bisnis waralaba di Indonesia mulai marak sejak tahun 1970-an. Jumlah perusahaan waralaba di Indonesia mencapai 35 perusahaan, 6 diantaranya adalah perusahaan waralaba lokal dan sisanya (29) adalah waralaba asing (www.neraca.co.id, 1 Maret 2012). Beberapa restoran cepat saji tumbuh berkembang seperti : Kentucky Fried Chicken (KFC), Mc Donald's, Domino's Pizza, dan Gokana Teppan. Ketersediaan makanan cepat saji (fast food) dirasakan sangat tepat untuk memenuhi keinginan dan gaya hidup masyarakat yang menginginkan sesuatu serba praktis.
\end{abstract}

Persaingan yang ketat menyebabkan suatu restoran perlu melakukan usaha pelayanan yang terbaik kepada konsumennya, strategi distribusi (delivery service) menjadi salah satu pilihan. Penelitian ini mengambil objek adalah KFC (Kentucky Fried Chicken) dan Mc Donalds Cabang Buah Batu, dikarenakan dari segi produk dan pelayanan selain memiliki banyak kesamaan, kedua restoran cepat saji ini merupakan restoran yang paling diminati atau dikunjungi oleh banyak masyarakat, terutama usia anak-anak dan remaja.

Dalam penelitian ini menggunakan metode descriptive komparatif dan eksplanatori, dengan populasi berdasarkan jumlah transaksi terbanyak di KFC untuk bulan Januari- maret 2012. Teknik sampling yang digunakan adalah Teknik Purposive Sampling dengan pengambilan secara acak (simple random sampling). Adapun jumlah responden/sampel dengan menggunakan perhitungan Slovin. Selanjutnya dilakukan analisis berdasarkan indeks kinerja kepuasan, uji Wilcoxon dan Importance Performance Analysis (IPA), dalam perhitungannya menggunakan software SPSS.

Hasil penelitian menunjukkan bahwa persepsi konsumen cukup baik untuk kualitas pelayanan delivery service yang dilakukan oleh KFC maupun Mc. Donald's, tetapi terdapat perbedaan berarti pada atribut-atribut pelayanan yang diberikannya, yaitu Mc. Donald's relatif lebih unggul dibandingkan dengan KFC. Oleh karena itu perlu dilakukan strategi yang berbeda untuk masing-masing atribut pelayanan manasaja sesuai hasil pemetaan diagram kartesius untuk ditingkatkan, dipertahankan, ataupun dipertimbangkan, agar kedua restoran cepat saji ini tatap tumbuh.

Kata kunci : Kualitas pelayanan jasa, delivery service, Indeks kinerja kepuasan, dan Importance Performance Analysis 


\section{PENDAHULUAN}

\section{Latar Belakang}

Menurut data Top Brand Tahun 2009-2011, Kentucky Fried Chicken (KFC) adalah salah satu restoran waralaba asing Indonesia yang berhasil mendapatkan predikat "Top Brands" kategori fast food (top brand.marketing.co.id, 3 Februari 2012). Kesuksesan KFC justru memicu persaingan yang ketat dalam industri restoran cepat saji dan membuat restoran-restoran cepat saji lainnya melakukan upaya-upaya yang bertujuan untuk meningkatkan kualitas produk dan pelayanannya. Demikian untuk pesaing pada tanggal 22 Februari 1991 hingga tanggal 21 Juni 2011 tercatat ada 111 gerai restoran yang telah dibuka oleh Mc Donald's (www.mcdonalds.co.id, April 2012).

Bisnis waralaba di Indonesia mulai tumbuh sejak tahun 1970-an, dengan bermunculannya restoran-restoran cepat saji seperti Kentucky Fried Chicken dan Pizza Hut. Hingga tahun 1992 jumlah perusahaan waralaba di Indonesia mencapai 35 perusahaan, 6 diantaranya adalah perusahaan waralaba lokal dan sisanya (29) adalah waralaba asing (www.neraca.co.id, 1 Maret 2012). Ketersediaan makanan cepat saji (fast food) dirasakan sangat tepat untuk memenuhi keinginan dan gaya hidup masyarakat sekarang ini yang menginginkan sesuatu serba praktis. Restoran cepat saji yang berkembang sekarang ini contohnya adalah KFC, Mc Donald's, Pizza Hut, Domino's Pizza, dan Gokana Teppan.

Persaingan yang ketat tersebut menyebabkan suatu restoran perlu melakukan usahausaha pelayanan yang terbaik kepada konsumennya. Hal ini menyebabkan restoranrestoran yang ada saling berlomba untuk menyediakan kemudahan dan kelengkapan produk yang sesuai dengan keinginan konsumen untuk tercapainya kepuasan pelanggan. Strategi distribusi menjadi salah satu pilihan yang berkembang saat ini, salah satu diantaranya adalah sistem delivery service (layanan antar). Dari segi produk dan pelayanan KFC dan Mc Donald's selain memiliki banyak kesamaan, kedua restoran cepat saji ini merupakan restoran yang paling diminati atau dikunjungi oleh banyak masyarakat, terutama usia anak-anak berkaitan dengan acara ulang tahun, dan remaja tempat mereka janjian berkumpul atau sekedar makan bersama. Oleh karena itu biasanya keluarga yang mau menikmati makan bersama keluarga secara praktis, mereka akan memesan pada salah satu restoran siap saji yang terkenal mereknya, sebagaimana dalam publikasi dalam internet menujukkan bahwa KFC dan Mc. Donald's termasuk dalam the Top fast Food Brands. (http://www.ranker.com/crowdranked-list/top-fast-food-brands). Oleh karena itu penelitian ini mengambil objek penelitian adalah KFC (Kentucky Fried Chicken) dan Mc Donalds Cabang Buah Batu.

Kualitas pelayanan, menjadi faktor penting yang bepengaruh dalam penciptaan kepuasan pelanggan. Menciptakan peningkatan kepuasan pelanggan menjadi isu penting bagi perusahaan karena manfaatnya. Dalam jangka pendek, kepuasan pelanggan menghasilkan loyalitas yang mengarah kepada profitabilitas. Perusahaan 
yang menginginkan tercapainya kepuasan pelanggan hendaknya memenuhi kebutuhan konsumennya.

\section{Tujuan Penelitian}

Mengacu pada permasalahan di atas, maka tujuan penelitian ini adalah:

1. Mengetahui sejauh mana kualitas pelayanan delivery service $\mathrm{KFC}$ dan $M c$ Donald's Cabang Buah Batu?

2. Mengetahui adakah perbedaan kualitas layanan jasa yang diberikan oleh delivery service KFC dengan Mc Donald's Cab. Buah Batu?

3. Mengetahui strategi yang harus dilakukan oleh delivery service KFC dengan Mc Donald's Cab. Buah Batu?

\section{Landasan Teori dan Pengembangan Hipotesis}

Menurut Tjiptono dan Chandra (2011:17) berpendapat bahwa jasa merupakan aktivitas, manfaat, atau kepuasan yang ditawarkan untuk dijual. Menurut Kotler \& Keller (2009:36), jasa/layanan (service) adalah semua tindakan atau kinerja yang dapat ditawarkan satu pihak kepada pihak lain yang pada intinya tidak berwujud dan tidak menghasilkan kepemilikan apapun. Produksinya dapat atau tidak terkait dengan produk fisik.

Kepuasan (Satisfaction) secara umum adalah perasaan senang atau kecewa seseorang yang timbul karena membandingkan kinerja yang dipersepsikan produk (atau hasil) terhadap ekspektasi mereka. Jika kinerja gagal memenuhi ekspektasi, pelanggan akan tidak puas. Jika kinerja sesuai dengan ekspektasi, pelanggan akan puas. Jika kinerja melebihi ekspektasi, pelanggan akan sangat puas atau senang. (Kotler \& Keller 2009:138)

Sedangkan menurut Lovelock \& Wright (2007 : 96) kepuasan konsumen atau kepuasan pelanggan adalah reaksi emosional jangka pendek pelanggan terhadap kinerja suatu jasa. Menurut Olson \& Dover (Tjiptono \& Chandra 2011:181) Harapan pelanggan merupakan keyakinan pelanggan sebelum mencoba atau membeli suatu produk, yang dijadikan standar atau acuan dalam menilai kinerja produk yang bersangkutan.

Kualitas jasa merupakan evaluasi kognitif jangka panjang pelanggan terhadap penyerahan jasa suatu perusahaan. Pengukuran kualitas jasa dapat diukur dengan dimensi kualitas jasa. Terdapat 5 dimensi kualitas jasa menurut Lovelock \& Wright (2007 : 98), yaitu :Kehandalan (Reliability) yaitu ; Apakah perusahaan dapat diandalkan dalam menyediakan jasa seperti yang dijanjikan. Keberwujudan (Tangible), yaitu: fasilitas fisik, perlengkapan, karyawan, dan bahan komunikasi penyedia jasa tersebut. Daya Tanggap (Responsiveness) yaitu : karyawan perusahaan tersebut senang membantu dan mampu memberikan jasa yang cepat. Jaminan (Assurance) yaitu : karyawan jasa memiliki pengetahuan yang cukup, sopan, kompeten, dan dapat dipercaya. Empati (Empathy) yaitu : perusahaan jasa 
memberikan perhatian yang besar dan khusus.

Adapun rumusan hipotesis dalam penelitian untuk melihat ada tidaknya perbedaan kualitas pelayanan delivery service pada KFC dengan Mc Donald's Cabang. Buah Batu penulis bersifat netral dengan mengajukan hipotesis sebagai berikut :

$\mathrm{H}_{0}$ : Tidak ada perbedaan yang berarti persepsi konsumen untuk kualitas pelayanan jasa KFC dan Mc Donald's Cabang Buah Batu.

$\mathrm{H}_{1}$ : Ada perbedaan yang berarti persepsi konsumen untuk kualitas pelayanan jasa KFC dan Mc Donald's Cabang Buah Batu.

\section{Metode Penelitian}

Penelitian ini dengan objek penelitian adalah KFC Cabang Buah Batu dan Mc Donald's Cabang Buah Batu periode Februar-Juli 2012. Metode dalam penelitian adalah deskriptif-komparatif dan eksplanatory. Penelitian deskriptif digunakan untuk memahami karakteristik sebuah kelompok dalam situasi tertentu, memikirkan secara sistematis mengenai berbagai aspek dalam situasi tertentu, memberikan gagasan untuk penyelidikan dan penelitian lebih lanjut, dan atau membuat keputusan tertentu yang sederhana (Sekaran, 2006:158-160). Sedangkan metode komparatif adalah penelitian yang membandingkan keberadaan satu variabel atau lebih pada dua atau lebih sampel yang berbeda, atau pada waktu yang berbeda. (Sugiyono 2012:36).

Secara teoritis menurut Hatch \& Farhady (Sugiyono, 2012:38) variabel dapat didefinisikan sebagai atribut seseorang, atau obyek, yang mempunyai "variasi" antara satu orang dengan yang lain atau satu obyek dengan obyek lain. Dalam penelitian ini menggunakan operasional variabel kualitas pelayanan delivery service yang terdiri dari : Reliability, Tangible, Responsiveness, Assurance, dan Empathy.

Skala Instrumen yang digunakan skala likert. Menurut Sugiyono (2010 146), menyebutkan skala likert digunakan untuk mengukur sikap, pendapat, dan persepsi seseorang atau sekelompok orang tentang fenomena sosial. Penelitian ini menggunakan data primer dengan menyebarkan kuesioner kepada para konsumen yang pernah memesan pada KFC dan $M c$ Donald's. Selain itu data sekunder melalui studi kepustakaan, buku, internet, dan informasi lain yang dapat memperdalam peneletian.

Populasi diambil berdasarkan jumlah transaksi terbanyak di KFC Cabang Buah Batu. untuk bulan Januari 2.389, februari 2.115, dan maret sebanyak 2.312 transaksi. Hal itu karena, delivery service tidak menggunakan jumlah konsumen sebagai indikator penjualannya, melainkan menggunakan transaksi.

Teknik sampling yang digunakan adalah Teknik Purposive Sampling dengan pengambilan responden secara acak (simple random sampling). Dalam penelitian ini responden yang dijadikan sample adalah seorang yang memenuhi kriteria yaitu pernah melakukan pemesanan pada KFC dan Mc Donald's. Adapun untuk mendaptkan respondenya peneliti pada waktuwaktu tertentu mendatangi konsumen disekitar area KFC dan Mc,Donald's untuk meminta kesediaan mengisi kusetioner berkaitan dengan pelayanan delivery service. Besarnya sampel atau jumlah responden dengan menggunakan perhitungan Slovin yang dikutip oleh (Umar 1999:49) sebagai berikut : 
Dimana :

$\mathrm{n}=$ Ukuran sampel

$\mathrm{N}=$ Ukuran populasi

$$
n=\frac{N}{1+N\left(e^{2}\right)}
$$

$\mathrm{e}=\%$ Kelonggaran ketidaktelitian karena kesalahan pengambilan keputusan sampel yang masih dapat ditolelir (batas kesalahan $\pm 10 \%$ ) diperoleh sampel sebanyak :

$$
n=\frac{2.389}{1+2.389\left(0.1^{2}\right)} \approx 95,98
$$

Untuk sampel yang representative digunakan masing-masing sebanyak 100 responden yang pernah melakukan pemesanan produk pada KFC dan Mc Donald's Cabang Buah Batu.

Uji validitas dan reliabilitas merupakan salah satu aspek penting dalam menyusun maupun memverivikasi kuesioner. Peritungan validitas dan reabilitas yang dilakukan dengan Software SPSS diperoleh semua pernyataan memiliki nilai korelasi di atas 0,367 shingga setiap butir pernyataan dinyatakan valid. Adapun uji reliabilitas menggunakan teknik Alpha Croanbach. Hasil pengolahan data reliabilitas Cronbach's Alpha diperoleh atas 0,60 yaitu sebesar 0,94, maka variabel kualitas pelayanan delivery service dinyatakan reliabel.

Untuk mengetahui indeks kinerja kualitas pelayanan (kepuasan pelanggan) dapat digunakan rumus yang dikemukankan Lovelock \& Wright sebagai berikut:

\section{Kepuasan}

Jasa yang dipahami (Perceived Service Quality)

Jasa yang diharapkan (Expected Service Quality)

Hasil jawaban kuesioner responden akan dilakukan pengolahan secara deskriptive yaitu diberikan scoring 1 sampai 4, sehingga nilai prosentase tertinggi adalah $100 \%$ dan terendah $25 \%$. Nilai rentang prosentase $75 \%$ dan dibagi 4 katagori, maka didapatkan nilai interval prosentase mendekati 19\%. Sehingga diperoleh klasifikasi sebagai berikut :

\begin{tabular}{|c|c|c|c|}
\hline $\begin{array}{c}\text { Skor } \\
\text { Jawaban }\end{array}$ & $\begin{array}{c}\text { Kategori } \\
\text { Jawaban }\end{array}$ & $\begin{array}{c}\text { Kategori } \\
\text { (Prosentase) }\end{array}$ & $\begin{array}{c}\text { Keterangan } \\
\text { Jawaban }\end{array}$ \\
\hline 1 & Sangat Tidak Setuju & $25 \%-43 \%$ & Tidak Baik \\
\hline 2 & Tidak Setuju & $44 \%-62 \%$ & Kurang Baik \\
\hline 3 & Setuju & $63 \%-81 \%$ & Cukup Baik \\
\hline 4 & Sangat Setuju & $82 \%-100 \%$ & Baik \\
\hline
\end{tabular}

Untuk mengetahui ada tidaknya perbedaan kualitas pelayanan jasa yang dipersepsikan konsumen dilakukan uji beda. Menurut Suharyadi \& Purwanto (2009:234), uji jumlah peringkat wilcoxon dirancang untuk menentukan apakah dua sampel yang independen berasal dari populasi yang sama, serta jumlah observasi yang relevan cukup besar.

Uji jumlah peringkat Wilcoxon digunakan uji Z dengan rumus sebagai berikut: 


$$
Z=\frac{W\left|\frac{n_{1} ; n_{1}-\eta_{2}+1}{2}\right|}{v \frac{n_{1} !_{2}\left(n_{1}-\tau_{2}+1\right)}{12}}
$$

Dimana : Z : Nilai Z-hitung

$\mathrm{W}$ : Jumlah peringkat sampel pertama

$\mathrm{n}_{1}$ : Jumlah observasi sampel relevan pertama

$\mathrm{n}_{2}$ : Jumlah observasi sampel relevan kedua

Selanjutnya untuk melihat strategi yang harus dilakukan dalam kualitas pelayanan menggunakan Importance Performance Analysis (IPA) merupakan suatu metode analisis yang bertujuan menggambarkan kinerja sebuah objek dibandingkan dengan harapan konsumen akan kinerja yang seharusnya ada, menggunakan Diagram Cartesius. (Riyanto, 2009:141).

Konsep ini sebenarnya berasal dari konsep SERVQUAL. Intinya, sebagaimana disarankan oleh Pasuraman (Rangkuti, 2006:109), tingkat kepentingan pelanggan (customer expectation) diukur dalam kaitannya dengan apa yang seharusnya dikerjakan oleh perusahaan agar menghasilkan produk atau jasa yang berkualitas tinggi. Expectation sebaiknya diganti dengan Importance atau tingkat kepentingan menurut persepsi pelanggan dapat digambarkan menjadi 4 kuadran yaitu : kuadran 1 (attributes to improve), kuadran II (maintain performance), Kuadran III (attributes to maintain) dan kuadran IV (main priority)

\section{Hasil dan Pembahasan}

\section{Kualitas Pelayanan Delivery Service KFC dan Mc. Donal's}

Kepuasan konsumen dalam memesan makanan siap saji pada KFC dan Mc. Donal's pada penelitian ini diukur dengan menggunakan metode Indeks Kinerja Kepuasan, Berdasarkan hasil jawaban kuestioner reponden pemesan KFC diperoleh hasil indeks kinerja sebagai berikut :

TABEL 1

Indeks Penilaian Kepuasan Pelanggan KFC

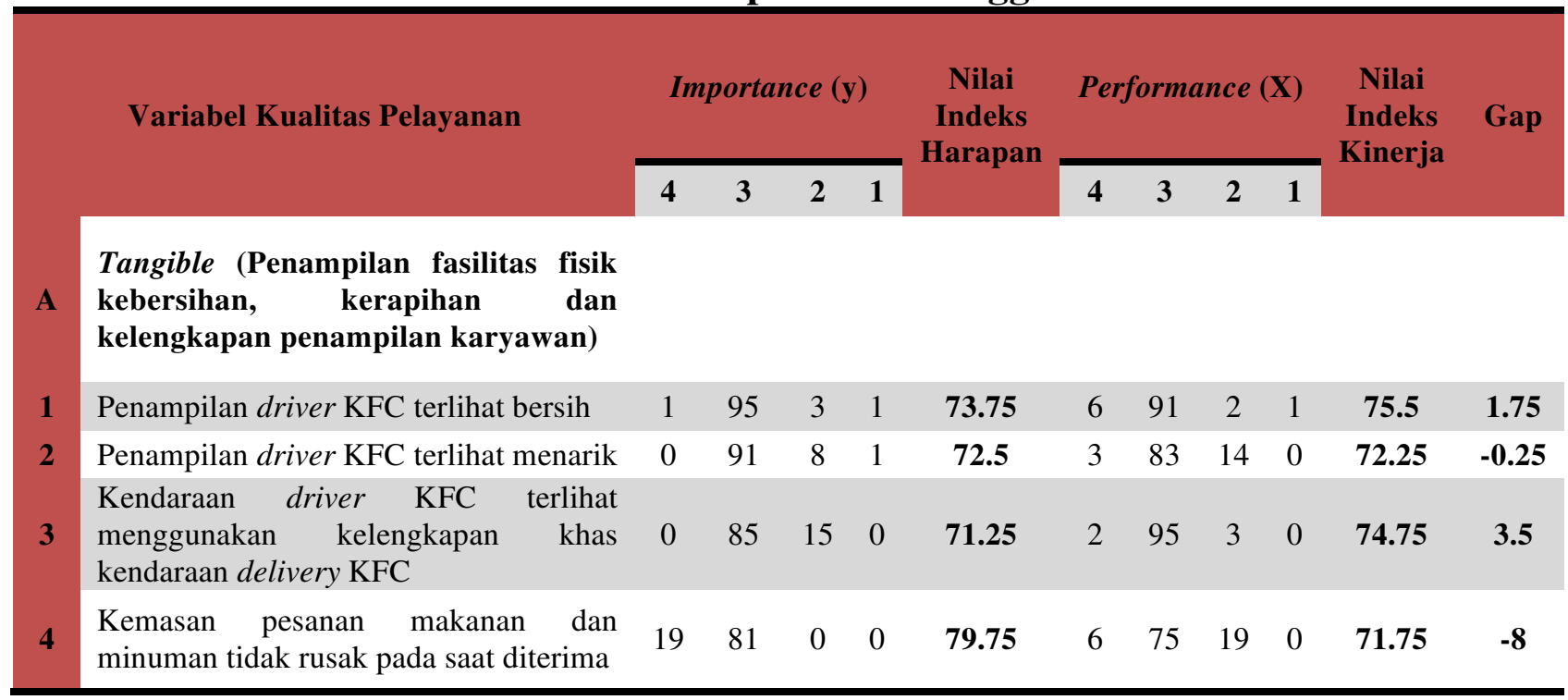




\begin{tabular}{|c|c|c|c|c|c|c|c|c|c|c|c|c|}
\hline & Rata-rata & & & & & 74.31 & & & & & 73.56 & -0.75 \\
\hline B & $\begin{array}{lll}\text { Reliability (Kemampuan untuk } \\
\text { memberikan pelayanan yang } & \text { sesuai } \\
\text { dengan janji yang ditawarkan) }\end{array}$ & & & & & & & & & & & \\
\hline 5 & $\begin{array}{l}\text { Pengiriman pesanan dalam layanan } \\
\text { pesan antar KFC cepat. }\end{array}$ & 24 & 76 & 0 & 0 & 81 & 1 & 70 & 27 & 2 & 67.5 & -13.5 \\
\hline 6 & $\begin{array}{l}\text { Makanan yang dipesan masih dalam } \\
\text { keadaan hangat ketika diterima } \\
\text { pelanggan }\end{array}$ & 13 & 83 & 4 & 0 & 77.25 & 5 & 56 & 34 & 5 & 65.25 & -12 \\
\hline 7 & $\begin{array}{l}\text { Dalam pelayanannya, driver } \mathrm{KFC} \\
\text { bersikap ramah. }\end{array}$ & 18 & 82 & 0 & 0 & 79.5 & 2 & 81 & 17 & 0 & 71.25 & -8.25 \\
\hline 8 & $\begin{array}{l}\text { Dalam pelayanannya, operator bersikap } \\
\text { ramah dalam menerima telepon }\end{array}$ & 19 & 70 & 11 & 0 & 77 & 21 & 68 & 11 & 0 & 77.5 & 0.5 \\
\hline 9 & $\begin{array}{l}\text { Layanan pesan antar KFC memudahkan } \\
\text { konsumen dalam pembelian jarak jauh }\end{array}$ & 8 & 90 & 2 & 0 & 76.5 & 9 & 91 & 0 & 0 & 77.25 & 0.75 \\
\hline & Rata-rata & & & & & 78.25 & & & & & 71.75 & -6.5 \\
\hline $\mathrm{C}$ & $\begin{array}{l}\text { Responsiveness (respon atau kesigapar } \\
\text { karyawan dalam membantu pelangga } \\
\text { dan memberikan pelayanan yang cepa } \\
\text { dan tanggap, yang meliputi: kesigapa } \\
\text { karyawan dalam melayani pelanggan } \\
\text { kecepatan karyawan dalam menangan } \\
\text { transaksi, dan penanganan keluha } \\
\text { pelanggan) }\end{array}$ & & & & & & & & & & & \\
\hline 10 & $\begin{array}{l}\text { Driver KFC menginformasikan kepada } \\
\text { pelanggan tentang kepastian waktu } \\
\text { pesanan tiba. }\end{array}$ & 13 & 86 & 1 & 0 & 78 & 3 & 90 & 5 & 2 & 73.5 & -4.5 \\
\hline 11 & $\begin{array}{l}\text { Pelanggan mudah mengakses call } \\
\text { center KFC jika akan melakukan } \\
\text { pesanan }\end{array}$ & 6 & 94 & 0 & 0 & 76.5 & 16 & 84 & 0 & 0 & 79 & 2.5 \\
\hline 12 & $\begin{array}{l}\text { Karyawan/ti KFC menanggapi keluhan } \\
\text { pelanggan dengan baik }\end{array}$ & 31 & 69 & 0 & 0 & 82.75 & 1 & 62 & 36 & 1 & 65.75 & -17 \\
\hline 13 & $\begin{array}{l}\text { Driver KFC selalu menyediakan uang } \\
\text { kembalian }\end{array}$ & 15 & 77 & 7 & 1 & 76.5 & 8 & 92 & 0 & 0 & 77 & 0.5 \\
\hline & Rata-rata & & & & & 78.44 & & & & & 73.81 & -4.63 \\
\hline D & $\begin{array}{l}\text { Assurance (Meliputi Kemampuan } \\
\text { karyawan atas: pengetahuan } \\
\text { terhadap produk secara tepat, } \\
\text { kualitas keramahtamahan, perhatian } \\
\text { dan kesopanan dalam memberi } \\
\text { pelayanan, keterampilan dalam } \\
\text { memberikan informasi, kemampuan } \\
\text { dalam memberikan keamanan di } \\
\text { dalam memanfaatkan jasa yang } \\
\text { ditawarkan, dan kemampuan dalam } \\
\text { menanamkan kepercayaan pelanggan } \\
\text { terhadap perusahaan) }\end{array}$ & & & & & & & & & & & \\
\hline 14 & $\begin{array}{l}\text { Karyawan/ti KFC mempunyai } \\
\text { pengetahuan yang luas mengenai menu }\end{array}$ & 11 & 85 & 3 & 1 & 76.5 & 13 & 85 & 2 & 0 & 77.75 & 1.25 \\
\hline
\end{tabular}




\begin{tabular}{|c|c|c|c|c|c|c|c|c|c|c|c|c|}
\hline 15 & $\begin{array}{l}\text { Karyawan/ti KFC mempunyai } \\
\text { kemampuan untuk menjelaskan menu } \\
\text { kepada pelanggan }\end{array}$ & 0 & 100 & 0 & 0 & 75 & 16 & 69 & 15 & 0 & 75.25 & 0.25 \\
\hline 16 & $\begin{array}{l}\text { Pesanan yang diantar selalu sesuai } \\
\text { dengan apa yang dipesan pelanggan }\end{array}$ & 14 & 86 & 0 & 0 & 78.5 & 21 & 70 & 9 & 0 & 78 & -0.5 \\
\hline 17 & $\begin{array}{l}\text { KFC memberikan refund/penukaran } \\
\text { pesanan jika terjadi kesalahan pada } \\
\text { pesanan }\end{array}$ & 16 & 83 & 1 & 0 & 78.75 & 7 & 70 & 21 & 2 & 70.5 & -8.25 \\
\hline 18 & $\begin{array}{l}\text { Makanan dan minuman yang dipesan } \\
\text { selalu tersedia }\end{array}$ & 10 & 86 & 4 & 0 & 76.5 & 11 & 89 & 0 & 0 & 77.75 & 1.25 \\
\hline & Rata-rata & & & & & 77.05 & & & & & 75.85 & -1.2 \\
\hline $\mathbf{E}$ & $\begin{array}{l}\text { Emphaty } \\
\text { (Perhatian secara individual yang } \\
\text { diberikan perusahaan kepada } \\
\text { pelanggan seperti kemudahan untuk } \\
\text { menghubungi perusahaan, } \\
\text { kemampuan karyawan untuk } \\
\text { berkomunikasi dengan pelanggan, } \\
\text { dan usaha perusahaan untuk } \\
\text { memahami keinginan dan kebutuhan } \\
\text { pelanggannya) }\end{array}$ & & & & & & & & & & & \\
\hline 19 & $\begin{array}{l}\text { Driver KFC selalu menyiapkan } \\
\text { kebutuhan pelanggan walaupun tidak } \\
\text { diminta (contoh memberikan tambahan } \\
\text { tissue, sendok dan sebagainya) }\end{array}$ & 7 & 93 & 0 & 0 & 76.75 & 10 & 86 & 4 & 0 & 76.5 & -0.25 \\
\hline 20 & $\begin{array}{l}\text { Operator KFC sabar dalam menghadapi } \\
\text { konsumen }\end{array}$ & 17 & 83 & 0 & 0 & 79.25 & 11 & 82 & 7 & 0 & 76 & -3.25 \\
\hline 21 & $\begin{array}{l}\text { Driver KFC sabar dalam menunggu } \\
\text { konsumen membuka pintu untuk } \\
\text { mengambil pesanan }\end{array}$ & 6 & 94 & 0 & 0 & 76.5 & 7 & 93 & 0 & 0 & 76.75 & 0.25 \\
\hline 22 & $\begin{array}{l}\text { Operator KFC memberikan salam } \\
\text { ketika telepon pertama kali diangkat } \\
\text { dan memberikan ucapan terimakasih } \\
\text { setelah selesai melakukan pemesanan. }\end{array}$ & 11 & 87 & 2 & 0 & 77.25 & 16 & 84 & 0 & 0 & 79 & 1.75 \\
\hline \multirow[t]{3}{*}{23} & $\begin{array}{l}\text { Driver KFC mengucapkan salam ketika } \\
\text { bertemu dengan pelanggan, dan } \\
\text { mengucapkan terimakasih setelah } \\
\text { transaksi pembayaran dilakukan }\end{array}$ & 26 & 73 & 1 & 0 & 81.25 & 26 & 70 & 4 & 0 & 80.5 & -0.75 \\
\hline & Rata-rata & & & & & 78.2 & & & & & 77.75 & -0.45 \\
\hline & Rata-Rata Kesenjangan Keseluruhan & & & & & 77.33 & & & & & 74.62 & -2.71 \\
\hline
\end{tabular}

Sumber : Hasil Pengolahan Data Kuesioner

Berdasarkan Tabel 1. di atas, menunjukkan rata-rata nilai nilai indeks kinerja KFC Cabang

Buah Batu adalah 74,62 dan dapat dikatagorikan kinerja kualitas pelayanan KFC Cabang Buah Batu cukup baik dalam melayani pesanan konsumennya.

TABEL 2

Indeks Penilaian Kepuasan Pelanggan Mc Donald's

\begin{tabular}{|c|c|c|c|c|c|c|c|c|c|c|c|}
\hline \multirow{2}{*}{ Variabel Kualitas Pelayanan } & \multicolumn{4}{|c|}{ Importance $(\mathbf{y})$} & \multirow{2}{*}{$\begin{array}{l}\text { Nilai } \\
\text { Indeks } \\
\text { Harapa }\end{array}$} & \multicolumn{4}{|c|}{$\begin{array}{c}\text { Performance } \\
\text { (X) }\end{array}$} & \multirow{2}{*}{$\begin{array}{l}\text { Nilai } \\
\text { Indeks } \\
\text { Kinerj }\end{array}$} & \multirow{2}{*}{ Gap } \\
\hline & 4 & 3 & 2 & 1 & & 4 & 3 & 2 & 1 & & \\
\hline
\end{tabular}




\begin{tabular}{|c|c|c|c|c|c|c|c|c|c|c|c|c|}
\hline & & & & & & $\mathbf{n}$ & & & & & $\mathbf{a}$ & \\
\hline $\mathbf{A}$ & $\begin{array}{l}\text { Tangible (Penampilan fasilitas fisik } \\
\text { kebersihan, kerapihan dan } \\
\text { kelengkapan } \\
\text { karyawan) }\end{array}$ & & & & & & & & & & & \\
\hline 1 & $\begin{array}{l}\text { Penampilan driver } \mathrm{McD} \text { terlihat } \\
\text { bersih }\end{array}$ & 9 & $\begin{array}{l}8 \\
5\end{array}$ & 6 & 0 & 75.75 & 8 & 90 & 2 & 0 & 76.5 & 0.75 \\
\hline 2 & $\begin{array}{l}\text { Penampilan driver } \mathrm{McD} \text { terlihat } \\
\text { menarik }\end{array}$ & 9 & $\begin{array}{l}7 \\
0\end{array}$ & $\begin{array}{l}2 \\
0\end{array}$ & 1 & 73.75 & 13 & 87 & 0 & 0 & 78.25 & 4.5 \\
\hline 3 & $\begin{array}{l}\text { Kendaraan driver McD terlihat } \\
\text { menggunakan kelengkapan khas } \\
\text { kendaraan delivery } \mathrm{McD}\end{array}$ & $\begin{array}{l}1 \\
1\end{array}$ & $\begin{array}{l}8 \\
2\end{array}$ & 7 & 0 & 78.25 & 14 & 86 & 0 & 0 & 78.5 & 0.25 \\
\hline 4 & $\begin{array}{lll}\text { Kemasan } & \text { pesanan makanan dan } \\
\text { minuman tidak rusak pada saat } \\
\text { diterima }\end{array}$ & $\begin{array}{l}1 \\
9\end{array}$ & $\begin{array}{l}7 \\
4\end{array}$ & 7 & 0 & 80.75 & 8 & 87 & 5 & 0 & 75.75 & -5 \\
\hline & Rata-rata & & & & & 77.13 & & & & & 77.25 & 0.13 \\
\hline B & $\begin{array}{l}\text { Reliability (Kemampuan untuk } \\
\text { memberikan pelayanan yang sesuai } \\
\text { dengan janji yang ditawarkan) }\end{array}$ & & & & & & & & & & & \\
\hline 5 & $\begin{array}{l}\text { Pengiriman pesanan dalam layanan } \\
\text { pesan antar McD cepat }\end{array}$ & $\begin{array}{l}1 \\
7\end{array}$ & $\begin{array}{l}7 \\
9\end{array}$ & 4 & 0 & 78.25 & 15 & 69 & 15 & 1 & 74.5 & $\overline{-}$ \\
\hline 6 & $\begin{array}{l}\text { Makanan yang dipesan masih dalam } \\
\text { keadaan hangat ketika diterima } \\
\text { pelanggan }\end{array}$ & $\begin{array}{l}2 \\
0\end{array}$ & $\begin{array}{l}7 \\
5\end{array}$ & 5 & 0 & 78.75 & 22 & 68 & 10 & 0 & 78 & $\overline{-} \overline{75}$ \\
\hline 7 & $\begin{array}{l}\text { Dalam pelayanannya, driver } \mathrm{McD} \\
\text { bersikap ramah }\end{array}$ & 8 & $\begin{array}{l}7 \\
9\end{array}$ & $\begin{array}{l}1 \\
2\end{array}$ & 1 & 73.5 & 14 & 72 & 13 & 1 & 74.75 & 1.25 \\
\hline 8 & $\begin{array}{l}\text { Dalam pelayanannya, } \\
\text { bersikap ramah dalam merator } \\
\text { telepon }\end{array}$ & $\begin{array}{l}1 \\
2\end{array}$ & $\begin{array}{l}7 \\
5\end{array}$ & $\begin{array}{l}1 \\
3\end{array}$ & 0 & 74.75 & 12 & 79 & 9 & 0 & 75.75 & 1 \\
\hline 9 & $\begin{array}{l}\text { Layanan pesan antar } \text { McD } \\
\text { memudahkan konsumen } \\
\text { pembelian jarak jauh }\end{array}$ & $\begin{array}{l}1 \\
3\end{array}$ & $\begin{array}{l}8 \\
6\end{array}$ & 1 & 0 & 78 & 16 & 84 & 0 & 0 & 79 & 1 \\
\hline & Rata-rata & & & & & 76.65 & & & & & 76.4 & $\overline{-} \overline{25}$ \\
\hline $\mathrm{C}$ & $\begin{array}{l}\text { Responsiveness } \begin{array}{l}\text { (respon } \\
\text { kesigapan karyawan dau } \\
\text { membantu pelanggan dam }\end{array} \\
\text { memberikan pelayanan yang cepat } \\
\text { dan tanggap, yang meliputi: } \\
\text { kesigapan karyawan dalam } \\
\text { melayani pelanggan, kecepatan } \\
\text { karyawan dalam menangani } \\
\text { transaksi, dan penanganan keluhan } \\
\text { pelanggan) }\end{array}$ & & & & & & & & & & & \\
\hline $\begin{array}{l}1 \\
\mathbf{0}\end{array}$ & $\begin{array}{l}\text { Driver McD menginformasikan } \\
\text { kepada pelanggan tentang kepastian } \\
\text { waktu pesanan tiba. }\end{array}$ & $\begin{array}{l}1 \\
4\end{array}$ & $\begin{array}{l}8 \\
6\end{array}$ & 0 & 0 & 78.5 & 35 & 65 & 0 & 0 & 83.75 & 5.25 \\
\hline 1 & $\begin{array}{l}\text { Pelanggan mudah mengakses call } \\
\text { center McD jika akan melakukan } \\
\text { pesanan }\end{array}$ & $\begin{array}{l}1 \\
7\end{array}$ & $\begin{array}{l}7 \\
9\end{array}$ & 4 & 0 & 78.25 & 29 & 71 & 0 & 0 & 82.25 & 4 \\
\hline
\end{tabular}




\begin{tabular}{|c|c|c|c|c|c|c|c|c|c|c|c|c|}
\hline $\begin{array}{l}1 \\
2\end{array}$ & $\begin{array}{l}\text { Karyawan/ti McD menanggapi } \\
\text { keluhan pelanggan dengan baik }\end{array}$ & $\begin{array}{l}1 \\
7\end{array}$ & $\begin{array}{l}8 \\
2\end{array}$ & 1 & 0 & 79 & 19 & 81 & 0 & 0 & 79.75 & 0.75 \\
\hline $\begin{array}{l}1 \\
3\end{array}$ & $\begin{array}{l}\text { Driver McD selalu menyediakan uang } \\
\text { kembalian }\end{array}$ & 7 & $\begin{array}{l}7 \\
4\end{array}$ & $\begin{array}{l}1 \\
9\end{array}$ & 0 & 72 & 9 & 79 & 12 & 0 & 74.25 & 2.25 \\
\hline & Rata-rata & & & & & 76.94 & & & & & 80 & 3.06 \\
\hline D & 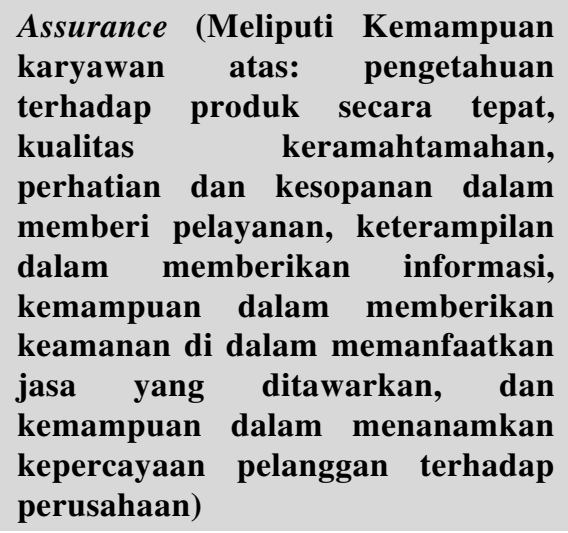 & & & & & & & & & & & \\
\hline $\begin{array}{l}1 \\
4\end{array}$ & $\begin{array}{l}\text { Karyawan/ti McD mempunyai } \\
\text { pengetahuan yang luas mengenai } \\
\text { menu }\end{array}$ & $\begin{array}{l}2 \\
2\end{array}$ & $\begin{array}{l}7 \\
5\end{array}$ & 3 & 0 & 79.75 & 28 & 72 & 0 & 0 & 82 & 2.25 \\
\hline $\begin{array}{l}1 \\
5\end{array}$ & $\begin{array}{l}\text { Karyawan/ti McD mempunyai } \\
\text { kemampuan untuk menjelaskan menu } \\
\text { kepada pelanggan }\end{array}$ & 6 & $\begin{array}{l}8 \\
7\end{array}$ & 7 & 0 & 74.75 & 15 & 76 & 9 & 0 & 76.5 & 1.75 \\
\hline $\begin{array}{l}1 \\
6\end{array}$ & $\begin{array}{l}\text { Pesanan yang diantar selalu sesuai } \\
\text { dengan apa yang dipesan pelanggan }\end{array}$ & $\begin{array}{l}1 \\
6\end{array}$ & $\begin{array}{l}8 \\
4\end{array}$ & 0 & 0 & 79 & 20 & 80 & 0 & 0 & 80 & 1 \\
\hline $\begin{array}{l}1 \\
7\end{array}$ & $\begin{array}{l}\text { McD memberikan refund/penukaran } \\
\text { pesanan jika terjadi kesalahan pada } \\
\text { pesanan }\end{array}$ & $\begin{array}{l}2 \\
5\end{array}$ & $\begin{array}{l}7 \\
4\end{array}$ & 1 & 0 & 81 & 16 & 71 & 12 & 1 & 75.5 & -5.5 \\
\hline $\begin{array}{l}1 \\
8\end{array}$ & $\begin{array}{l}\text { Makanan dan minuman yang dipesan } \\
\text { selalu tersedia }\end{array}$ & $\begin{array}{l}2 \\
5\end{array}$ & $\begin{array}{l}7 \\
5\end{array}$ & 0 & 0 & 81.25 & 17 & 82 & 1 & 0 & 79 & $2 . \overline{25}$ \\
\hline & Rata-rata & & & & & 79.15 & & & & & 78.6 & $\overline{-}$ \\
\hline $\mathbf{E}$ & $\begin{array}{l}\text { Emphaty } \\
\text { (Perhatian secara individual yang } \\
\text { diberikan perusahaan kepada } \\
\text { pelanggan seperti kemudahan } \\
\text { untuk menghubungi perusahaan, } \\
\text { kemampuan karyawan untuk } \\
\text { berkomunikasi dengan pelanggan, } \\
\text { dan usaha perusahaan untuk } \\
\text { memahami keinginan dan } \\
\text { kebutuhan pelanggannya) }\end{array}$ & & & & & & & & & & & \\
\hline $\begin{array}{l}1 \\
9\end{array}$ & $\begin{array}{l}\text { Driver McD selalu menyiapkan } \\
\text { kebutuhan pelanggan walaupun tidak } \\
\text { diminta (contoh memberikan } \\
\text { tambahan tissue, sendok dan } \\
\text { sebagainya) }\end{array}$ & $\begin{array}{l}1 \\
3\end{array}$ & $\begin{array}{l}8 \\
7\end{array}$ & 0 & 0 & 78.25 & 24 & 76 & 0 & 0 & 81 & 2.75 \\
\hline $\begin{array}{l}2 \\
\mathbf{0}\end{array}$ & $\begin{array}{l}\text { Operator McD sabar dalam } \\
\text { menghadapi konsumen }\end{array}$ & $\begin{array}{l}1 \\
7\end{array}$ & $\begin{array}{l}8 \\
3\end{array}$ & 0 & 0 & 79.25 & 14 & 77 & 17 & 2 & 80.75 & 1.5 \\
\hline
\end{tabular}




\begin{tabular}{|c|c|c|c|c|c|c|c|c|c|c|c|c|}
\hline $\begin{array}{l}2 \\
1\end{array}$ & $\begin{array}{l}\text { Driver McD sabar dalam menunggu } \\
\text { konsumen membuka pintu untuk } \\
\text { mengambil pesanan }\end{array}$ & $\begin{array}{l}1 \\
1\end{array}$ & $\begin{array}{l}8 \\
7\end{array}$ & 2 & 0 & 77.25 & 22 & 76 & 2 & 0 & 80 & 2.75 \\
\hline $\begin{array}{l}2 \\
2\end{array}$ & $\begin{array}{l}\text { Operator McD memberikan salam } \\
\text { ketika telepon pertama kali diangkat } \\
\text { dan memberikan ucapan terimakasih } \\
\text { setelah selesai melakukan pemesanan. }\end{array}$ & $\begin{array}{l}1 \\
9\end{array}$ & $\begin{array}{l}8 \\
1\end{array}$ & 0 & 0 & 79.75 & 15 & 86 & 17 & 0 & 88 & 8.25 \\
\hline $\begin{array}{l}2 \\
3\end{array}$ & $\begin{array}{l}\text { Driver McD mengucapkan salam } \\
\text { ketika bertemu dengan pelanggan, dan } \\
\text { mengucapkan terimakasih setelah } \\
\text { transaksi pembayaran dilakukan }\end{array}$ & $\begin{array}{l}1 \\
6\end{array}$ & $\begin{array}{l}8 \\
4\end{array}$ & 0 & 0 & 79 & 19 & 81 & 0 & 0 & 79.75 & 0.75 \\
\hline & Rata-rata & & & & & 78.7 & & & & & 81.9 & 3.2 \\
\hline & Rata-Rata Keseluruhan & & & & & 77.77 & & & & & 78.85 & 1.08 \\
\hline
\end{tabular}

Sumber : Hasil Pengolahan Data Kuesioner

Berdasarkan Tabel 2. Di atas nilai rata-rata indeks kinerja Mc Donald's Cabang Buah Batu adalah 78,85 dan dapat dikatagorikan kinerja kualitas pelayanan Mc Donald's Cabang Buah Batu cukup baik dalam melayani pesanan konsumennya.

\section{Uji Beda Kinerja Kualitas Pelayanan Service Delivery KFC dan Mc Donald's}

Pelayanan yang diberikan oleh produsen merupakan salah satu faktor yang menjadi pilihan bagi konsumen untuk menentukan pesanan produk/makanan siap saji pada kedua restoran tersebut. Kelebihan dan kekurangan atas indicator/atribut kualitas pelayanan delivery service dan persepsi konsumen berkaitan dengan ada tidaknya perbedaan yang berarti atas kepuasan kinerja delivery service pada KFC dan Mc.Donal's menggunakan uji Wilcoxon. Hasil uji peringkat kinerja indikator /atribut kualitas pelayanan delivery service yang dilakukan oleh KFC dan Mc. Donald's dapat dijabarkan pada Tabel 3 dan Tabel 4 sebagai berikut :

Tabel 3

Wilcoxon Signed Ranks Test Ranks

\begin{tabular}{|c|c|c|c|c|}
\hline \multicolumn{5}{|c|}{ Ranks } \\
\hline & & $\mathrm{N}$ & Mean Rank & Sum of Ranks \\
\hline \multirow{4}{*}{ KFC - McD } & Negative Ranks & $20^{a}$ & 13.08 & 261.50 \\
\hline & Positive Ranks & $3^{b}$ & 4.83 & 14.50 \\
\hline & Ties & $0^{c}$ & & \\
\hline & Total & 23 & & \\
\hline \multicolumn{5}{|c|}{ a. $\mathrm{KFC}<\mathrm{McD}$} \\
\hline \multicolumn{5}{|c|}{ b. $\mathrm{KFC}>\mathrm{McD}$} \\
\hline c. $\mathrm{KFC}=\mathrm{Mc}$ & & & & \\
\hline
\end{tabular}

Sumber: Hasil Pengolahan data.

1) Negative Ranks merupakan selisih antara kinerja indikator kualitas pelayanan delivery service yang dilakukan oleh KFC dan Mc. Donald's bernilai negatif yaitu sebanyak 20 
Indikator/atribut dari total 23 indikator/atribut. Dari hasil tersebut dapat dikatakan bahwa persepsi pemesan produk siap saji terhadap kinerja kualitas pelayanan delivery service KFC sebanyak 20 indikator lebih rendah dibandingkan dengan kinerja kualitas pelayanan delivery service yang dilakukan oleh Mc. Donald's.

2) Positive Ranks merupakan selisih antara kinerja indikator kualitas pelayanan delivery service yang dilakukan oleh KFC dan Mc. Donald's bernilai positif yaitu sebanyak 3 Indikator/atribut dari total 23 indikator/atribut. Dari hasil tersebut dapat dikatakan bahwa persepsi pemesan produk siap saji terhadap kinerja kualitas pelayanan delivery service KFC sebanyak 3 indikator/atribut lebih tinggi dibandingkan dengan kinerja kualitas pelayanan delivery service yang dilakukan oleh Mc. Donald's.

3) Ties merupakan hasil dimana tidak ada perbedaan di antara keduanya. Dalam penelitian ini jumlah Ties adalah 0 indikator/atribut. Dari hasil tersebut dapat dikatakan bahwa persepsi pelanggan pemesan produk terhadap kinerja kualitas pelayanan delivery service adalah sama untuk keduanya.

TABEL 4.

Z-hitung Uji Peringkat Nilai Indeks Kinerja KFC dan Mc Donald's Cabang Buah Batu

\begin{tabular}{|lr|}
\hline \multicolumn{2}{|c|}{ Test Statistics $^{\text {b }}$} \\
Z & KFC - McD \\
Asymp. Sig. (2-tailed) & $-3.757^{\mathrm{a}}$ \\
a. Based on positive ranks. & .000 \\
b. Wilcoxon Signed Ranks Test & \\
\multicolumn{2}{|c|}{ Sumber: Hasil Pengolahan Data }
\end{tabular}

Nilai Asymp Sig Z hitung adalah 0.000 lebih kecil dibandingkan dengan $\alpha=0,05$. Maka $\mathrm{H}_{0}$ ditolak dan $\mathrm{H}_{1}$ diterima sehingga dapat ditarik kesimpulan bahwa ada perbedaan yang berarti antara kualitas pelayanan jasa KFC dan Mc Donald's Cabang Buah Batu atau dapat dikatakan Kualitas Pelayanan delivery service Mc Donald's Cabang Buah Batu relative lebih baik dipersepsikan konsumennya dibandingkan dengan kualitas pelayanan delivery service yang dilakukan KFC Cabang Buah Batu.

\section{Strategi}

Strategi yang harus dilakukan untuk berbagai atribut-atribut kualitas pelayanan pada masing-masing restoran siap saji berdasarkan teknik Importance Performance Analysis (IPA). Metode ini dilakukan dengan cara setiap responden diminta untuk menilai tingkat kepentingan berbagai siap atribut yang relevan dan tingkat kinerja perusahaan (perceived performance). Berdasarkan hasil pengolahan IPA diperoleh mapping berbagai atribut dalam bentuk diagram sebagai berikut : 


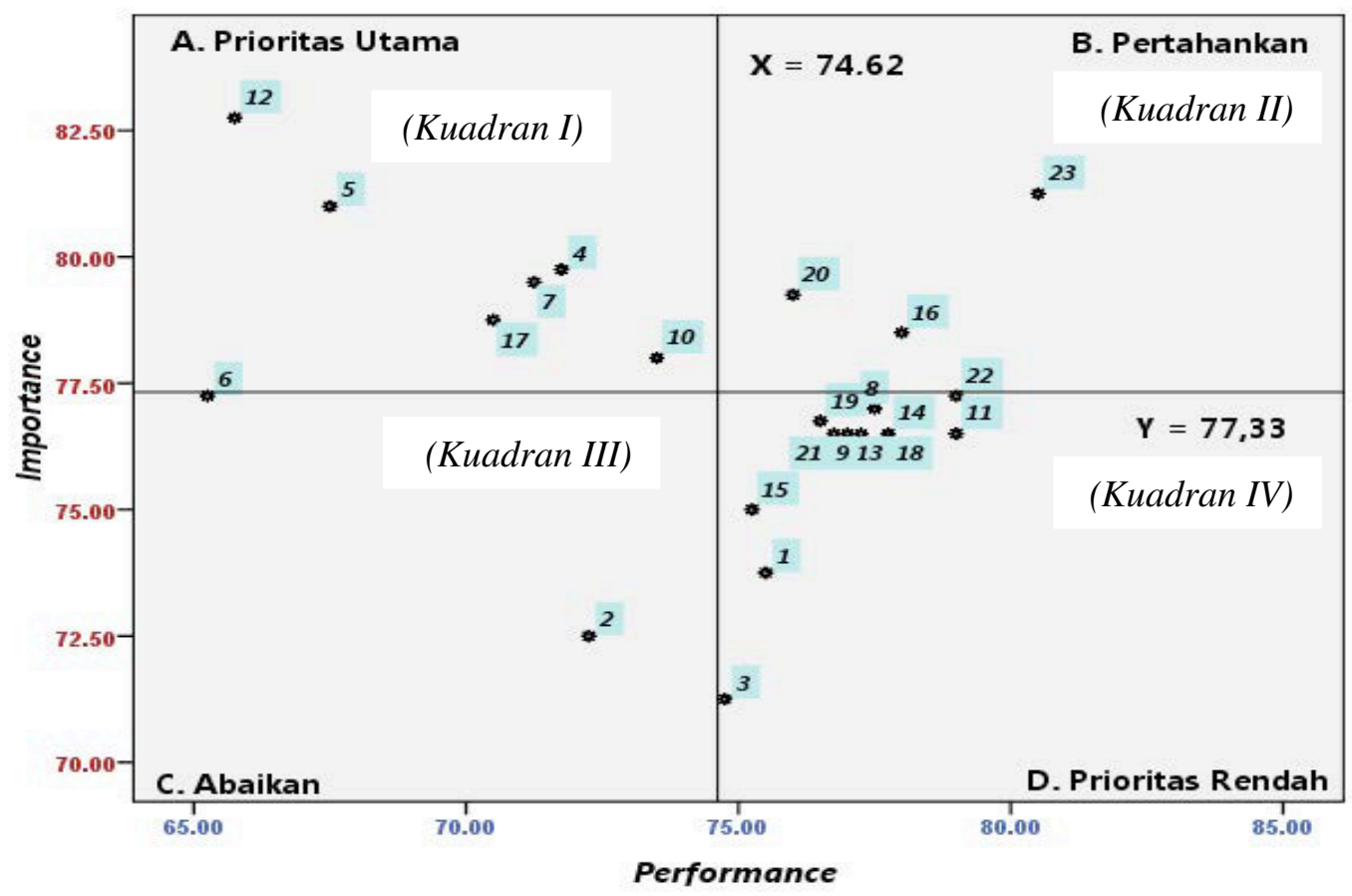

GAMBAR 1

Diagram Kartesius Atribut Kualitas Pelayanan KFC

Gambar 1 di atas,. menunjukkan diagram kartesius yang mempertemukan tingkat kepentingan/harapan dan tingkat realitas terbagi menjadi 4 bagian yang dapat dijelaskan sebagai berikut:

a) Kuadran I (A. Prioritas Utama)

Atribut-atribut yang dianggap penting oleh konsumen tetapi pada kenyataannya belum sesuai seperti yang konsumen harapkan, sehingga perlu ditingkatkan atau menjadi prioritas, diantaranya : keadaan kemasan, kecepatan pengiriman, keramahan driver KFC, kesigapan driver KFC, respon keluhan pelanggan, dan jaminan terjadinya kesalahan dalam pemesanan.

b) Kuadran II (B. Pertahankan)

Atribut-atribut yang dianggap penting oleh konsumen dan sudah sesuai dengan yang dirasakannya sehingga patut dipertahankan, diantaranya: kesabaran operator KFC, pemberian salam oleh driver KFC dan kesesuaian pesanan yang diantar dengan yang dipesan.

c) Kuadran III (C. Diabaikan/Dipertimbangkan)

Atribut-atribut yang dianggap kurang penting oleh konsumen dan pada kenyataannya kinerjanya tidak terlalu istimewa, sehingga perlu dipertimbangkan kembali karena manfaat yang dirasakan oleh konsumen sangat kecil, diantaranya: penampilan driver KFC yang menarik dan keadaan makanan yang dipesan.

d) Kuadran IV (D. Prioritas Rendah)

Atribut-atribut yang dianggap kurang penting oleh konsumen tetapi KFC tetap memberikan pelayanan yang baik, diantaranya: kebersihan penampilan driver KFC, pemberian salam oleh operator KFC, kesabaran driver KFC, perhatian khusus yang diberikan driver kepada konsumen, jaminan tersediannya makanan/minuman yang dipesan, kemampuan untuk menjelaskan menu, pengetahuan karyawan/ti mengenai 
menu, kemudahan proses pembayaran, kemudahan dalam mengakses call center, kemudahan dalam mengkonsumsi (praktis), kelengkapan kendaraan driver KFC, dan keramahan operator KFC.

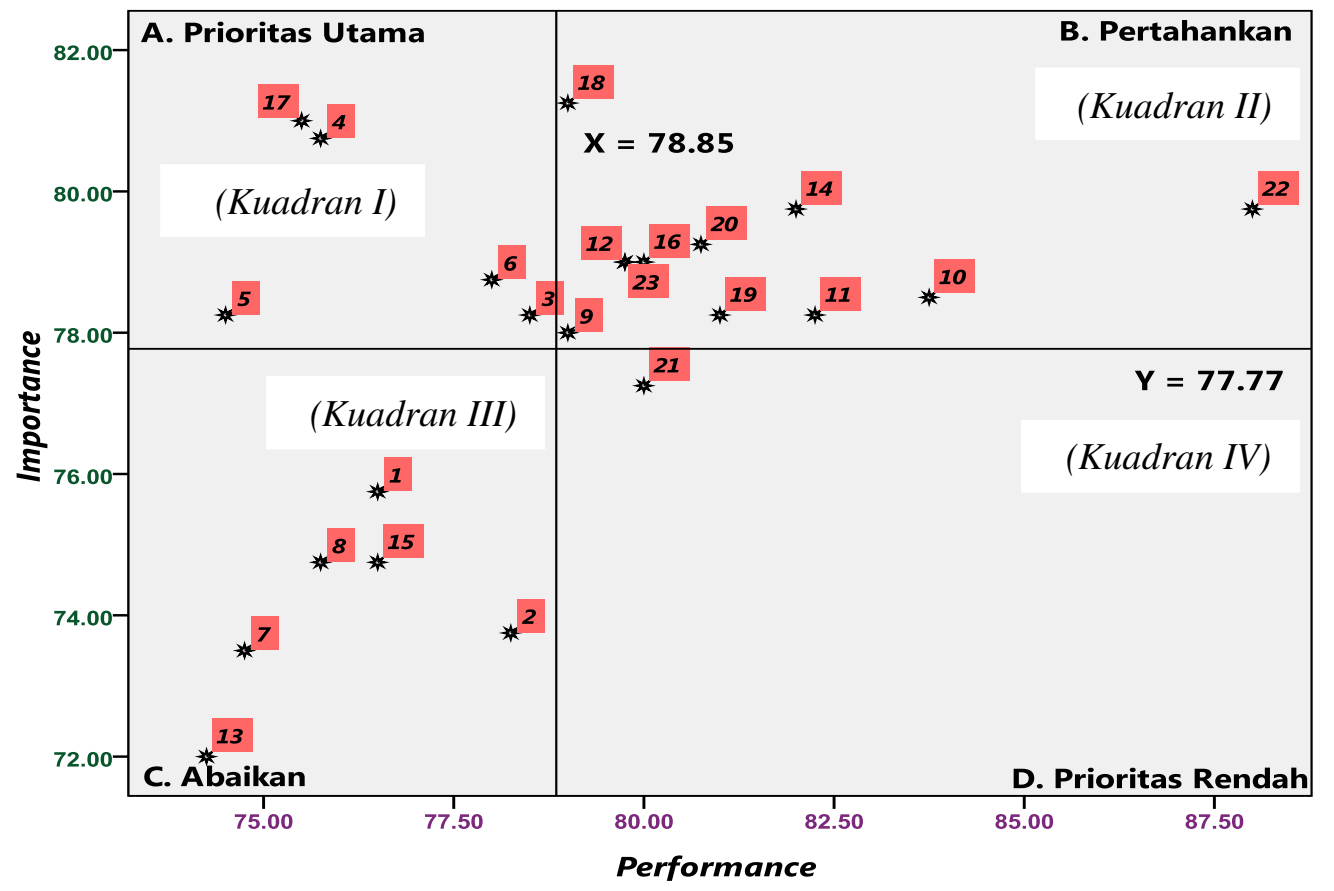

GAMBAR 2

Diagram Kartesius Atribut Kualitas Pelayanan Mc Donald's

Gambar 2 di atas, menunjukkan diagram kartesius yang mempertemukan tingkat kepentingan/harapan dan tingkat realitas terbagi menjadi 4 bagian yang dapat dijelaskan sebagai berikut:

a) Kuadran I (A. Prioritas Utama)

Atribut-atribut yang masuk dalam kuadran ini harus ditingkatkan atau menjadi prioritas, diantarany: jaminan terjadinya kesalahan dalam pemesanan, keadaan kemasan, kecepatan pengiriman, keadaan makanan yang dipesan, dan kelengkapan kendaraan driver Mc Donald's.

b) Kuadran II (B. Pertahankan)

Atribut-atribut yang dianggap penting oleh konsumen dan sudah sesuai dengan yang dirasakannya sehingga patut dipertahankan prestasinya. Diantaranya : kesabaran operator Mc Donald's, respon keluhan pelanggan, pengetahuan karyawan/ti mengenai menu, kesesuaian pesanan yang diantar dengan yang dipesan, kesigapan driver Mc Donald's, kemudahan dalam mengakses call center, perhatian khusus yang diberikan driver Mc Donald's, pemberian salam oleh operator Mc Donald's, pemberian salam oleh driver Mc Donald's, kemudahan dalam mengkonsumsi (praktis) dan jaminan tersedianya makanan/minuman.

c) Kuadran III (C. Diabaikan/Dipertimbangkan)

Atribut-atribut yang ini dapat dipertimbangkan kembali karena manfaat yang dirasakan oleh konsumen sangat kecil., diantaramya: kemampuan karyawan/ti untuk menjelaskan menu, keramahan operator Mc Donald's, kemudahan proses pembayaran, dan keramahan, kebersihan serta penampilan driver Mc Donald's yang menarik.

d) Kuadran IV (D. Prioritas Rendah) 
Atribut-atribut yang dianggap kurang penting oleh konsumen, tetapi MC. Donals tetap memberikan pelayanannya yang baik, yaitu diantaranya: kesabaran driver $M c$ Donald's.

\section{Kesimpulan}

Berdasarkan analisis kualitas pelayanan delivery service KFC dan Mc Donald's Cabang Buah Batu diperoleh kesimpulan sebagai berikut :

1. Indeks kinerja kualitas pelayanan delivery service KFC adalah sebesar 74,62 dan Mc. Donal's sebesar 78,85, kedua restoran ini memberikan pelayanan makanan siap saji cukup baik kepada para konsumen/pemesannya.

2. KFC dan Mc Donald's Cabang Buah Batu memiliki jenis produk yang hampir sama, tetapi dari segi kualitas pelayanan (atribut-atributnya) memiliki perbedaan yang berarti. Mc. Donald's relative lebih baik dipersepsikan oleh konsumen dalam memberikan kualitas pelayanan delivery service dibandingkan dengan KFC Cabang Buah Batu.

3. Strategi yang perlu dilakukan pada kedua restoran siap saji masing-masing sebagai berikut :

A. Atribut-atribut kualitas pelayanan KFC Cabang Buah Batu yang harus ditingkatkan menjadi prioritas adalah: keadaan kemasan, kecepatan pengiriman, keramahan driver KFC, kesigapan driver KFC, respon keluhan pelanggan, dan jaminan terjadinya kesalahan dalam pemesanan. Atribut-atribut patut dipertahankan prestasinya adalah: kesabaran operator KFC, pemberian salam oleh driver KFC dan kesesuaian pesanan yang diantar dengan yang dipesan. Atribut-atribut yang dipertimbangkan adalah: penampilan driver KFC yang menarik dan keadaan makanan yang dipesan. Atribut-atribut yang dianggap kurang penting oleh konsumen adalah: kebersihan penampilan driver KFC, pemberian salam oleh operator KFC, kesabaran driver KFC, perhatian khusus yang diberikan driver kepada konsumen, jaminan tersediannya makanan/minuman yang dipesan, kemampuan untuk menjelaskan menu, pengetahuan karyawan/ti mengenai menu, kemudahan proses pembayaran, kemudahan dalam mengakses call center, kemudahan dalam mengkonsumsi (praktis), kelengkapan kendaraan driver KFC, dan keramahan operator KFC.

B. Atribut-atribut kualitas pelayanan Mc. Donald's Cabang Buah Batuyang harus ditingkatkan atau menjadi prioritas adalah: jaminan terjadinya kesalahan dalam pemesanan, keadaan kemasan, kecepatan pengiriman, keadaan makanan yang dipesan, dan kelengkapan kendaraan driver Mc Donald's. Atribut-atribut yang harus dipertahankan adalah: kesabaran operator Mc Donald's, respon keluhan pelanggan, pengetahuan karyawan/ti mengenai menu, kesesuaian pesanan yang diantar dengan yang dipesan, kesigapan driver Mc Donald's, kemudahan dalam mengakses call center, perhatian khusus yang diberikan driver Mc Donald's, pemberian salam oleh operator Mc Donald's, pemberian salam oleh driver Mc Donald's, kemudahan dalam mengkonsumsi (praktis) dan jaminan tersedianya makanan/minuman. Atribut- 
atribut yang dipertimbangkan adalah: kemampuan karyawan/ti untuk menjelaskan menu, keramahan operator Mc Donald's, kemudahan proses pembayaran, keramahan driver Mc Donald's, kebersihan penampilan driver Mc Donald's, dan penampilan driver yang menarik, Atribut-atribut yang dianggap kurang penting oleh konsumen adalah kesabaran driver Mc Donald's.

\section{Saran}

Saran terhadap Perusahaan KFC dan Mc Donald's sesuai dengan hasil Importance Performance Analysis (IPA), yaitu atribut-atribut yang termasuk dalam kuadran I yang perlu ditingkatkan adalah sebagai berikut :

1. Untuk KFC Cabang Buah Batu adalah keadaan kemasan, kecepatan pengiriman, keramahan driver KFC, kesigapan driver KFC, respon keluhan pelanggan, dan jaminan terjadinya kesalahan dalam pemesanan harus diperbaiki/ditingkatkan dalam memenuhi pesanannya.

2. Untuk Mc.Donald's Cabang Buah Batu adalah jaminan terjadinya kesalahan dalam pemesanan, keadaan kemasan, kecepatan pengiriman, keadaan makanan yang dipesan, dan kelengkapan kendaraan driver Mc Donald's harus diperbaiki/ditingkatkan dalam memenuhi pesanannya.

3. Dalam merespon keluhan pelanggan perusahaan perlu menyediakan fasilitas tambahan untuk menampung dan memberikan solusi yang cepat dan langsung kepada pelanggan tidak hanya melalui SMS saja, misalnya melalui internet dengan Yahoo Mesengger, email dan lain-lain. 


\section{DAFTAR PUSTAKA}

Abdurrahman, Maman \& Muhidin, Sambas Ali. Panduan Praktis Memahami Penelitian. CV Pustaka Setia.

Jasfar, Farida. (2005). Manajemen Jasa Pendekatan Terpadu. Ghalia Indonesia.

Kotler, Philip \& Keller, Kevin Lane. 2009. Manajemen Pemasaran. Erlangga.

Lovelock \& Wright, Lauren K. 2007. Manajemen Pemasaran Jasa. PT Indeks Kelompok Gramedia.

PT. Fast Food Indonesia Tbk. 2011. Annual Report 2011. 1-60.

Rangkuti, Freddy. 2006. Teknik Mengukur dan Strategi Meningkatkan Kepuasan Pelanggan. PT Gramedia Pustaka Utama.

Redaksi.2012. KFC.[Online].http://topbrand.marketing.co.id/2012/02/03/kfc/ [3 Maret 2012].

Riyanto, Agus. 2009. Penerapan Analisi Multivariat dalam Penelitian Kesehatan. Niftramedia Press.

S.Soerono, Agus. 2012. Pasang Surut Bisnis Waralaba di Indonesia. [Online].http://www.neraca.co.id/2012/03/01/pasang-surut-bisnis-waralaba-diindonesia / [1 Maret 2012].

Sugiyono. 2012. Metode Penelitian Kuantitatif Kualitatif dan R\&D. Alfabeta.

Suharyadi \& Purwanto. 2009. STATISTIKA: Untuk Ekonomi dan Keuangan Model. Salemba Empat

Sunyoto, Danang. 2009. Analisis Regresi dan Uji Hipotesis. Media Pressindo.

Tjiptono, Fandy \& Chandra, Gregorius. 2011. Service, Quality, Satisfaction. CV Andi Offset.

Umar, Husein.1999. Metodologi Penelitian : Aplikasi Dalam Pemasaran. Gramedia.

Mc Donald's. 2012 [Online].http://www.mcdonalds.co.id [Maret 2012]

KFC.2006. [Online].http://www.kfcindonesia.com/ [Maret 2012]. 